\title{
Effects of Crime News on Emotional Response of Audience
}

\section{Huma ZE*}

Kohat University of Science and Technology, Pakistan

\begin{abstract}
The aim of this research is to find out the effects of Pakistani television news coverage of crime on the emotional response of youth. This study is conducted to explore the negative effects of crime news coverage on the youth. It was hypothesizes that "Watching crime news makes young people feel that they live in uncertain conditions". The study is quantitative in nature and a questionnaire with open ended questions is distributed amongst the drawn sample to assess the effect. Convenience method is used for collection of data from the target population of 150 males and females respectively, living in Rawalpindi and Islamabad. Cultivation theory is used for the current study. While carrying out the research it was observed that after watching crime news people have developed an insecure and perilous feeling about the society and people around them. They avoid interacting with strangers and are careful to move around and have developed concern about their families. It was concluded that females are much more affected by the impact of crime news than males.
\end{abstract}

\section{Keywords: Crime; Emotional response; Television; Coverage}

\section{Introduction}

This research highlights the effects of Pakistani television crime news coverage on emotional response of youth of Pakistan and little emphasis has been paid to affective responses. Emotional impact is maybe one of the attractions of crime coverage for channels seeking to draw viewers and crime coverage generates fear and anxiety in viewers trigger many of the worries about its effects. Moreover, we know that emotions can play a crucial role on the citizens while interpreting/ processing the shown information so we will evaluate the crime stories in respect to that. Coverage of crime news and crime reporting now days has become the essence of news at local, national or international level. Three basic sources for disseminating news in the society can be through news paper, internet and television, whereas, television coverage has the optimum impact on people as compared to other two medium.

In the present era television has become an effortless source of distributing news and entertainment which is easily accessible to the majority of the population. It shows the hard facts of our society very realistically (especially in the news) gains the trust of people and increase their belief about many things. Consequently it plays a predominant role in shaping the minds and behaviors of its viewers, laying impact on their emotions and attitudes.

In Pakistan with passing years television broadcasting has become a strong tool which has promoted freedom of expression. Specifically in covering different crimes, every news channel makes an endeavor not to leave any stone unturned while establishing facts. Apart from crime coverage in the news, special programs on crime reporting are aired all over the world. This has two obvious reasons. Firstly, competition level between the contemporary news channels is very high and every channel desires to seek lead from others by providing real time and rare news, resultantly, they try to cover every incident/ crime taking place anywhere. Secondly, to increase the viewership of their channel by frequently airing sensational and hype creating news, thereby, creating interest for the people. But in covering many crime stories, ethics and values of reporting crime are compromised because of which a news story can become a source of discomfort and can cause emotional disturbances in the viewers. Covering crime news may have positive/negative repercussions. With the increase in crime rate in our society it's reporting in television has also taken a boost and the most important factor to consider is its impact on the emotional responses of people especially the youth who are the building blocks of this society. Another other important aspect touched in this paper is the manipulation of crime story covered to make it attractive enough to catch maximum viewership.

The basic purpose of this research is to put forward the perception of youth of Pakistan about crime coverage and violence in Pakistani television news. Crime reporting is one of the main contents of the daily news nowadays. Many news channels (mostly private) report violence and crime in a way that they exceed the limitation of ethics and values of reporting. Crime content and violence being shown is open and clear. So this study has been taken up to examine effects of crime news coverage on the youth and would be directly proportional to positive or negative results as an outcome of the research.

Viewers of local television news across the world are regularly exposed to crime news stories. Crime stories have eventually become a major part of television news today. Crime is referred to breaking of rules or laws for which some governing power can ultimately order assurance. Different societies may define crime and crimes in a different way. Whereas, every crime violates the law, but not every violation of the law counts as a crime, for example, breaking of any contract may rank as offences or as violation. Modern societies generally view crimes as offences against the public or the state, distinguished from torts (offences against private parties that can give rise to a civil cause of action).

Crime story is any incident or happening taking place in the society which is against the laws and leads to violence. Any crime story that is covered by a news agency or is reported by a journalist becomes crime news. Both crime news and a crime story are a part of programming in media but the only difference is that crime news is just narrated in the

*Corresponding author: Huma ZE, Kohat University of Science and Technology, Pakistan Tel: 0922-52914407; E-mail: zilehuma300@gmail.com

Received May 04, 2015; Accepted May 14, 2015; Published May 24, 2015

Citation: Huma ZE (2015) Effects of Crime News on Emotional Response of Audience. J Mass Communicat Journalism 5: 257. doi:10.4172/2165-7912.1000257

Copyright: (c) 2015 Huma ZE. This is an open-access article distributed under the terms of the Creative Commons Attribution License, which permits unrestricted use, distribution, and reproduction in any medium, provided the original author and source are credited. 
news whereas a crime story can be broadcasted in form of news, drama, film or a depicted story. Journalists and news reporters are the primary sources of gathering crime news.

\section{Background}

Crime is the most frequently included topic in both local and national television news. Dorfman and colleagues examined 214 hours of local television news from 26 stations in California and found that more time was allotted to violent crime stories than to any other topic and such stories were treated as highly newsworthy, appearing in the first or second segments of the newscast. Similarly, examined the nightly network newscasts on $\mathrm{ABC}, \mathrm{CBS}$, and $\mathrm{NBC}$ over 13 years and determined that crime stories occupied an average of approximately 60 seconds per newscast, regardless of network. Crime reporting had been institutionalized in the western press in 1821, when the London Morning Herald hired John Wight to cover night sessions at Bow Street Court, where cops presented a procession of drunks and petty criminals, most of them poor East Enders.

"Emotions arise as a result of the way in which the situations that initiate them are construed by the person who experienced it [1]. People do not experience emotion randomly but rather as a product of their cognitive evaluations (appraisals) of an event or happening. Emotions reflect the information and beliefs that people have accessible when evaluating a situation, as well as how that situation fits with their values and goals. Different emotions can arise from the different assessments that people make of a given situation. So if frames alter the information and considerations subjects have at hand, cognitive appraisal models would predict that emotional outputs should differ. In some cases the emotions themselves may be different and in other cases the explanations people generate to explain or understand their emotional response may be different. Regarding news content, people's memory for news with negative images is also better than their memory for news without negative images. The bulk of studies indicate that the human brain has an automatic attention response to negatively compelling stimuli, and this point is supported in particular reference to TV news. From a biological perspective, negatively compelling images can efficiently elicit emotional arousal in viewers and cause them to immediately face dangers. From a cognitive psychological perspective, the emotional arousal elicited by those negatively compelling stimulus can shape cognition without a viewer's awareness of information processing. Moreover, Newhagen and Reeves study shows that negatively compelling images in television news influence how viewers process and retain news messages, causing viewers to have better memory of news after watching negative images in TV news.

Newhagen defines three primary emotional images-anger, fear, and disgust-in negative news and investigates the effects of emotional images on memory and approach-avoidance (or adaptive mechanism). The study indicates that anger-evoking images in negative news receive the highest approach scores, followed by fear-evoking images. Disgustevoking images in negative news receive the lowest score, which implies the highest avoidance rating. Moreover, there is a strong relationship between approach-avoidance response and memory for news content. Accordingly, viewers have the best memory for news from angerevoking images and the worst memory for news from disgust-evoking images in television news.

\section{Rationale}

The reason of studying crime coverage in television news is to analyze that what is the extent of effects, crime news shown on television news channels reflect upon audience emotions which eventually cause change in their behaviors'.

\section{Problem Statement}

Crime leads to many adverse outcomes in a society. The effect of portrayal of crime in television news on youth's emotional response is highlighted in this study. Crime is covered in a sensational way by our television channels which lead to change in mind sets. Emotional responses can include different kind of psychological transformation which can further lead to change in attitudes and behaviors.

\section{Objectives}

The main objectives of this research are:

To find out the effects of Crime news on emotional behavior of the audience

To gauge the perception of audience that females are more sensitive towards crime news coverage.

It is hypothesized that "Watching crime news makes young people feel that they live in uncertain conditions".

\section{Significance}

Emotional response of youth on crime news coverage is a topic not explored with these variables, what researchers are concerned in this research. This limitation of research makes it a topic worth to be explored. This study is very interesting and gives us an idea about the emotional responses of audience. This study highlights the way crime coverage in Pakistani television news is taking place and its negative and positive effects on our Audience. It broadens our vision about the fact that how the upcoming generations of Pakistan are being affected by the crime news stories in television news.

\section{Literature Review}

Local television news remains Pakistan's most popular news medium. In a 2003 statistics, almost $50 \%$ of the public said they get "most of their news" from local television, twice as many as said network television and four times as many as said they get most of their news from their local daily newspaper. People see local news as more factual and less focused on opinion than other news sources. Seven in ten Americans said their overall opinion of their local television news was favorable. When asked what they liked about local television, those who expressed a favorable opinion most frequently mentioned its ability to offer local stories that allowed them to remain connected to their communities and be informed about local affairs.

And what do citizens learn about from watching local television news? One thing they learn about is crime. Crime rates in most U.S. cities have been on the decline for a decade, yet local newscasts still seem to operate under the mantra, "if it bleeds, it leads". An analysis of local television news in 50 markets from 1998-2002 found that one quarter of all stories dealt with crime and that two fifths of lead stories dealt with crime. These findings are consistent with a large body of previous research. A number of studies have concluded that crime news dominates local television coverage and is more likely than other topics to lead the newscast. Violent crime in particular is given more play than is warranted by actual crime statistics. Violent crime is arguably more newsworthy than property crime although the latter is much more likely to occur. Yet this level of attention to violent crime seems excessive and, as many have argued, its effects may be troubling. Some scholars have found that the predominance of violence in local 
television news cultivates fear of crime. Gross and Aday found little evidence that local television viewing predicted increased fear once one takes account of personal experience, however they did find agenda setting effects. Those who watched local television news were significantly more likely to see crime as an important problem. This is not surprising since that would seem to be the message local news sends both through its level of crime coverage and its tendency to feature crime in the top stories. Several studies have also examined the portrayal of race in local television crime news.

Most of this work has found that news over represents AfricanAmericans as perpetrators of violence while under representing them in more sympathetic roles such as law enforcement personnel or victims of violence. Black perpetrators are also portrayed as more threatening than white perpetrators. While work which tries to compare the media portrayal of crime with arrest rates for different groups suggests a somewhat less distorted picture than work that focuses on comparing the types of roles African-Americans occupy in crime coverage or work that focuses on comparing the numbers of black and white perpetrators, the implications of this research for public attitudes is troubling. As Gilliam and Iyengar argue, coverage of this nature creates a "crime script" in which crime is violent and perpetrators are black. Repeated exposure to this script promotes and reinforces negative racial stereotypes. Kang uses the metaphor of the "Trojan Horse Virus" to describe how local television news of this nature can, without viewers' awareness and without intent on the part of news producers, create and reinforce associations between blacks and violence in the minds of citizens. Once this crime script is not just a news script, but part of the script or schema individuals carry around with them in their heads, it is not surprising that it will have consequences for how people think about politics and approach the world. Some evidence for these real world effects comes from experiments by political scientists and psychologists. For example, Duncan found that an act (an ambiguous shove) was interpreted as more violent when performed by a black than when the same act was performed by a white, consistent with the notion that "black" and "violent" has become linked in the minds of many individuals. Kang cites a study in which participants were to shoot an armed target but not an unarmed target. The target individual was either black or white, was holding either a gun or another object, and was presented in a realistic background. Under time pressure participants were more likely to mistakenly shoot an unarmed black target than an unarmed white target and more likely to mistakenly not shoot a white target that was armed than a black target that was armed. In other words, participants in the study were more likely to assume wrongly that a black individual was a criminal and assume wrongly that a white individual was not. Using an experimental design and survey analysis, Gilliam and Iyengar demonstrate that exposure to a black perpetrator in a local television news crime story increased whites' support for punitive crime policy and their tendency to attribute crime to personal failings.5 Priming a black crime suspect influenced people's assessments of the perpetrator, of presidential candidates, and of issues. Taken together, these studies suggest that the racial elements of local television crime news may have important and troubling effects [2].

Most studies of the effects of media violence have examined passive visual media (dramatic television and movies, television news, and music videos), that is, media that viewers observe only. However, there have also been a limited number of investigations of interactive visual media (video games and the Internet), media that viewers both observe and interact with. In this section, we examine both kinds of studies. Within each genre, we begin with experimental studies, in which cause and effect are unambiguous but the effects observed are short term.
Of necessity, the outcomes in these experiments tend to be physical aggression that is not life threatening, or else verbal aggression, aggressive thoughts, or aggressive emotions. We then turn to surveys, or cross-sectional studies, that provide a snapshot of the relation at one point in time between individuals' habitual consumption of media violence and their aggressive behavior [3].

These surveys often deal with more serious forms of physical aggression, but this type of methodology by itself is not as conclusive about causation as experimental studies are. For genres for which longitudinal studies exist, we conclude our review by examining how youths' habitual consumption of violence affects their violent and aggressive behavior later in life. Like cross-sectional investigations, longitudinal studies often examine serious physical aggression, but they generally provide better evidence about causal influences than can cross-sectional studies. Because of space constraints, we provide illustrative examples of carefully selected key studies in each area, rather than an exhaustive review of the research literature. However, in addition to discussing these selected studies, we describe (if available) meta-analyses that have aggregated the results of most major investigations to reach overall estimates of effect sizes. A meta-analysis essentially averages the effect sizes of multiple studies, and allows the researcher to ask whether a particular factor (e.g., exposure to media violence) is significantly linked to a particular outcome (e.g., violent behavior). There are several commonly used measures of effect size, any of which can be applied to experimental, co relational and longitudinal types of studies. To provide a common metric for this discussion, we have converted all effect sizes to correlation coefficients [4].

According to the world report on violence and health the exposure everywhere of children and young people to mass media is substantial and growing. It is therefore important to explore media exposure as a possible risk factor for interpersonal violence involving young people.

\section{Theoretical Framework}

\section{Cultivation theory}

This research comes under cultivation theory which states that the more a person is exposed to a message provided by the media, the more likely that person is to believe the message is real. It explains that the effects of television are cultivated in its viewers in a way that they cause a change in their thoughts, behaviors or attitudes. George Gerbner's Cultivation Theory is an extremely important principle in public relations for several reasons. However, it also has negative as well as positive effects. Cultivation Theory, put simply, states that the more a person is exposed to a message provided by the media, the more likely that person is to believe the message is real.

Cultivation Theory is often applied to people's perceptions of reality. For example, a person who watches a lot of crime shows on television will eventually believe that there is a lot of violent crime in the city in which he lives. This skewed world is called a "mediated reality". The theory also states that viewers who watch more television will be more influenced than those who watch less and that "the cumulative effect of television is to create a synthetic world that heavy viewers come to see as reality".

Cultivation theory and the mediated realities suggested by it is a double-edged sword for public relations practitioners. A reality skewed in favor of a company can be extremely helpful, but a reality skewed against a company can be the straw that breaks the camel's back, so to speak. If the public is against an entity, it surely will not last long in this country in which companies rely solely on the public's consumption 
Citation: Huma ZE (2015) Effects of Crime News on Emotional Response of Audience. J Mass Communicat Journalism 5: 257. doi:10.4172/21657912.1000257

Page 4 of 6

of a product. If a company is to survive negative media attacks, it must have established a solid reputation before and handle media relations well during a crisis. To maintain a good image companies need to use the expertise of public relations professionals [5].

\section{Methodolgy}

In this study our independent variable is the crime being covered in Pakistani television news and dependent variable would be the emotional response of the teenagers as this is the effect caused by the viewing of a certain kind of news Table 1 . Intervening variables can be the psychological state of a teenager and the surrounding environment of the society to which a teenager would imply the situation.

\section{Technique/Method}

To carry out this study the technique of survey method was followed. It was done through questionnaires. In which the sample was be asked to give correct and unbiased responses. On the basis of the results of the survey the researcher deduced the direction in which the research has taken place.

\section{Research design}

Research was quantitative in nature and involved a survey from the males and females residing in Rawalpindi and Islamabad. Aim of the research was to find out the effects of television news coverage of crime on youngsters, both male and females.

\section{Population and sample}

Population is males and females aging between 20-30 years of age

\begin{tabular}{|c|c|c|c|}
\hline \multicolumn{4}{|c|}{ Variables Entered/Removed ${ }^{\mathrm{b}}$} \\
\hline Model & Variables Entered & Variables Removed & Method \\
\hline 1 & $\begin{array}{l}\text { What kind of effects crime news } \\
\text { content leave upon females? }\end{array}$ & & Enter \\
\hline
\end{tabular}

\section{Model Summary}

\begin{tabular}{|l|l|l|l|l|}
\hline Model & $\mathrm{R}$ & $\mathrm{R}$ Square & Adjusted R Square & Std. Error of the Estimate \\
\hline 1 & $.157^{\mathrm{a}}$ & .025 & .018 & 2.10044
\end{tabular}

a. Predictors: (Constant), What kind of effects crime news content leave upon females?

\begin{tabular}{|c|c|c|c|c|c|c|}
\hline \multicolumn{7}{|c|}{ ANOVA $^{b}$} \\
\hline \multicolumn{2}{|c|}{ Model } & Sum of Squares & Df & Mean Square & $\mathrm{F}$ & Sig. \\
\hline \multirow[t]{3}{*}{1} & Regression & 16.545 & 1 & 16.545 & 3.750 & $.055^{a}$ \\
\hline & Residual & 652.955 & 148 & 4.412 & & \\
\hline & Total & 669.500 & 149 & & & \\
\hline
\end{tabular}

a. Predictors: (Constant), What kind of effects crime news content leave upon females?

b. Dependent Variable: Timings for watching crime news content

\begin{tabular}{|c|c|c|c|c|c|c|}
\hline \multicolumn{7}{|c|}{ Coefficients $^{a}$} \\
\hline \multicolumn{2}{|c|}{ Model } & \multicolumn{2}{|c|}{$\begin{array}{l}\text { Unstandardized } \\
\text { Coefficients }\end{array}$} & \multirow{2}{*}{$\begin{array}{l}\text { Standardized } \\
\text { Coefficients } \\
\text { Beta }\end{array}$} & \multirow[t]{2}{*}{$\mathrm{T}$} & \multirow[t]{2}{*}{ Sig. } \\
\hline & & B & Std. Error & & & \\
\hline \multirow[t]{2}{*}{1} & (Constant) & 5.932 & .560 & & 10.597 & .000 \\
\hline & $\begin{array}{l}\text { What kind of } \\
\text { effects crime news } \\
\text { content leave } \\
\text { upon females? }\end{array}$ & -.667 & .345 & -.157 & -1.937 & .055 \\
\hline
\end{tabular}

Table 1: Effects of crime news content on emotional response of Females.

\begin{tabular}{|l|l|l|l|l|}
\hline \multicolumn{4}{|l|}{ Model Summary } \\
\hline Model & $\mathrm{R}$ & R Square & Adjusted R Square & Std. Error of the Estimate \\
\hline 1 & $.111^{\mathrm{a}}$ & .012 & .006 & 2.11384 \\
\hline a. Predictors: (Constant), Does age effects the emotional responses of s?
\end{tabular}

a. Predictors: (Constant), Does age effects the emotional responses of $s$ ?

\begin{tabular}{l}
\begin{tabular}{|l|l|l|l|l|l|l|}
\hline \multicolumn{7}{|l|}{ ANOVA $^{\mathrm{b}}$} \\
\hline Model & Sum of Squares & Df & Mean Square & F & Sig. \\
\hline 1 & Regression & 8.192 & 1 & 8.192 & 1.833 & $.178^{\mathrm{a}}$ \\
\hline & Residual & 661.308 & 148 & 4.468 & & \\
\hline
\end{tabular} \\
\hline
\end{tabular}

\begin{tabular}{|c|c|c|c|c|c|c|}
\hline \multicolumn{7}{|c|}{ Coefficients $^{a}$} \\
\hline \multirow{2}{*}{\multicolumn{2}{|c|}{ Model }} & \multicolumn{2}{|c|}{$\begin{array}{l}\text { Unstandardized } \\
\text { Coefficients }\end{array}$} & \multirow{2}{*}{\begin{tabular}{|l} 
Standardized \\
Coefficients \\
Beta
\end{tabular}} & \multirow{2}{*}{$T$} & \multirow[t]{2}{*}{ Sig. } \\
\hline & & B & Std. Error & & & \\
\hline \multirow[t]{2}{*}{1} & (Constant) & 5.578 & .530 & & 10.532 & .000 \\
\hline & $\begin{array}{l}\text { Does age effects } \\
\text { the emotional } \\
\text { responses of } s ?\end{array}$ & -.471 & .348 & -.111 & -1.354 & .178 \\
\hline
\end{tabular}

Table 2: Effects of age differences on emotional response of s.

Table 2. Due to shortage of time convenient sampling is done. The sample taken in total is of 50 out of which 25 are males and 25 are females. The youngsters taken as sample are from different walks of life. The effects of television crime news coverage on individuals are studied relatively Table 3 .

\section{Instrument/Questionnaire}

Primarily, a pretest of the questionnaire was administered to a sample of 10 males/females to explore the validity and reliability of the questionnaire. After making the required changes as a result of pretesting a questionnaire was constructed having 23 items in total. The questionnaire was divided into three parts.

\section{Results and Findings}

The results are shown in Tables 1-3.

\section{Discussion}

This research has find out the regression between different variables. This article found that there is correlation between different variables. These variables stands on different position when applied regression on these variables. Linear regression analysis was conducted to predict the overall index. Three analyses are conducted. One was of existence of emotional response; second emotional response of female in reaction to crime news content. Third emotional response of male in reaction to crime news content. Rests of the predictions are grounded by open ended questions. A linear regression analysis was conducted with of different analysis. The regression equation demonstrates diverse results. The regression equation is measured significant. Effects of age differences on emotional response are presented with following majors in regression table;

\section{$\mathrm{R}=.111$}

R Square $=.012$

Sig $=.178$ 
Citation: Huma ZE (2015) Effects of Crime News on Emotional Response of Audience. J Mass Communicat Journalism 5: 257. doi:10.4172/21657912.1000257

\begin{tabular}{|c|c|c|c|}
\hline \multicolumn{4}{|c|}{ Variables Entered/Removed ${ }^{b}$} \\
\hline Model & Variables Entered & Variables Removed & Method \\
\hline 1 & $\begin{array}{l}\text { What kind of effects crime news } \\
\text { content leave upon males? }\end{array}$ & & Enter \\
\hline
\end{tabular}

\section{Model Summary}

\begin{tabular}{|l|l|l|l|l|}
\hline Model & $\mathrm{R}$ & R Square & Adjusted R Square & Std. Error of the Estimate \\
\hline 1
\end{tabular}

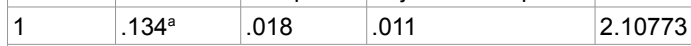

a. Predictors: (Constant), What kind of effects crime news content leave upon males?

\begin{tabular}{|c|c|c|c|c|c|c|}
\hline \multicolumn{7}{|c|}{ ANOVA $^{b}$} \\
\hline \multicolumn{2}{|c|}{ Model } & Sum of Squares & Df & Mean Square & $\mathrm{F}$ & Sig. \\
\hline \multirow[t]{3}{*}{1} & Regression & 12.004 & 1 & 12.004 & 2.702 & $.102^{\mathrm{a}}$ \\
\hline & Residual & 657.496 & 148 & 4.443 & & \\
\hline & Total & 669.500 & 149 & & & \\
\hline
\end{tabular}

a. Predictors: (Constant), What kind of effects crime news content leave upon males?

b. Dependent Variable: Timings for watching crime news content

\begin{tabular}{|c|c|c|c|c|c|c|}
\hline \multicolumn{7}{|c|}{ Coefficients $^{a}$} \\
\hline \multicolumn{2}{|c|}{ Model } & \multicolumn{2}{|c|}{$\begin{array}{l}\text { Unstandardized } \\
\text { Coefficients }\end{array}$} & \multirow{2}{*}{\begin{tabular}{|l|} 
Standardized \\
Coefficients \\
Beta
\end{tabular}} & \multirow[t]{2}{*}{$\mathrm{T}$} & \multirow[t]{2}{*}{ Sig. } \\
\hline & & B & Std. Error & & & \\
\hline \multirow[t]{2}{*}{1} & (Constant) & 5.761 & .551 & & 10.452 & .000 \\
\hline & $\begin{array}{l}\text { What kind of } \\
\text { effects crime news } \\
\text { content leave } \\
\text { upon males? }\end{array}$ & -.566 & .344 & -.134 & -1.644 & .102 \\
\hline
\end{tabular}

Table 3: Effects of crime news content on emotional response of male.

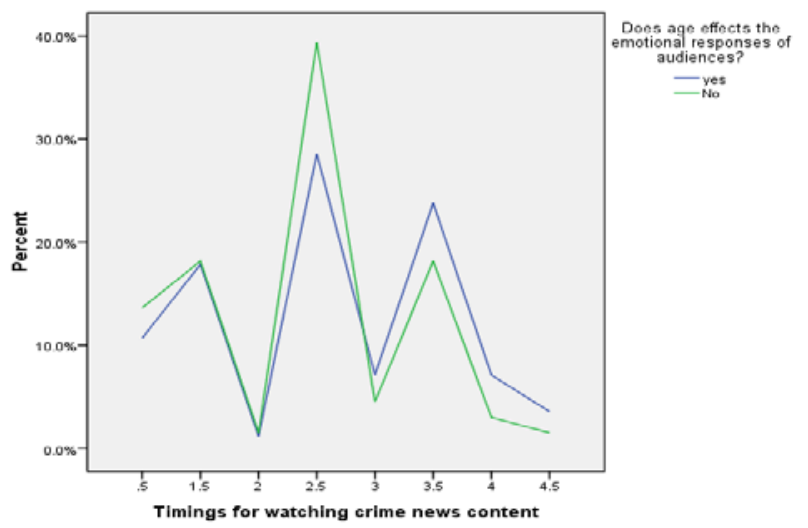

Figure 1: Age effects the emotional response of the audience.

$$
\mathrm{F}=1.833
$$

Bivariate correlation, partial correlation and the standardized correlation can be presented for analysis but here we are more concerned with regression line. The results of this analysis indicate that there is significant relation and regression among different predicators. It is appropriate to include that an initial description from the results that age is negatively correlated with content consumption of the audience. There is below the line connection between predicators and dependent variables. As Figure 1 showing that people with 2.5 hour consumption of crime content has more effects than people consuming 4 hours crime news content.
Second analysis predicts about efforts of crime news content upon females. It is positively correlated with the dependent variable. Crime news content has effects upon females. Females react to the crime content positively rather negative way. There are certain uncontrolled variables which effects with values of;

$\mathrm{R}=.157$

R Square $=.025$

Sig $=.005$

$\mathrm{F}=3.75$

As Figure 2 showing that the one who consume content has effects and these effects are same or close to each dimension either positive or negative. Third analysis shed lights upon effects on male in response to crime news content. This is evidence from the equation with following numerical values;

$\mathrm{R}=.134$

R Square $=.18$

Sig $=.102$

$\mathrm{F}=2.702$

Figure 3 also showed the same results with more details. Finally,

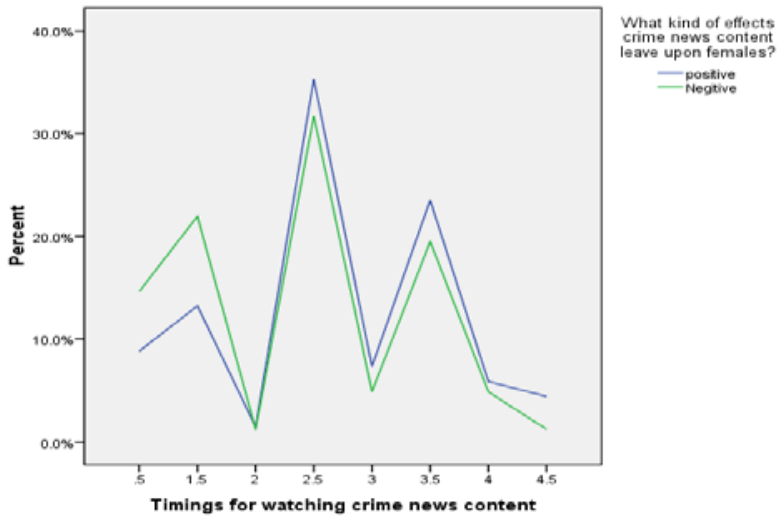

Figure 2: Effects of crime news content upon females.

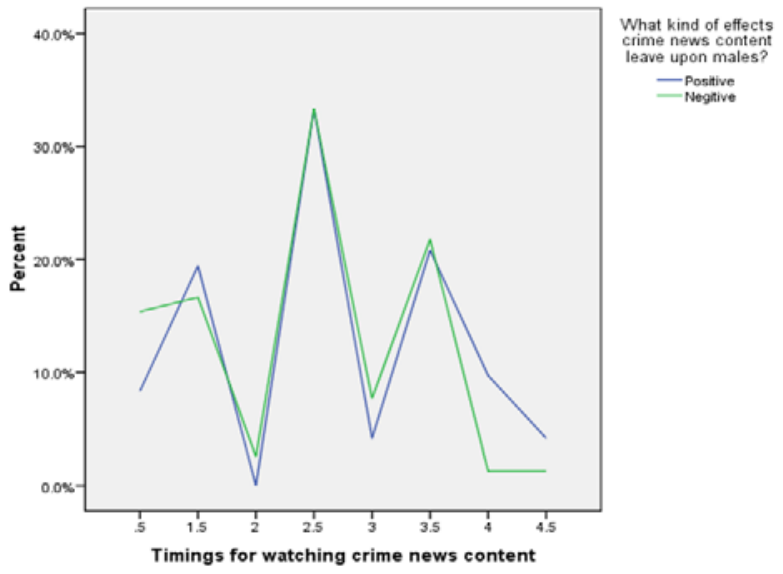

Figure 3: Effects of crime news content on emotional response of male audience. 


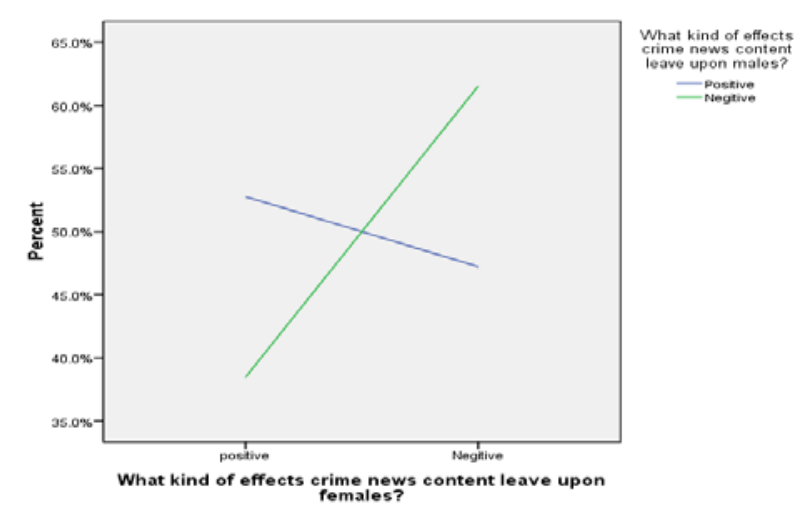

Figure 4: Effects of crime news content on emotional response; a comparison between male and female audience.

effects of crime news content upon females are positive where as effects upon male are negative. Women are less responsive to negate content or to react negatively in ratio than males. Figure 4 is evident of the elaboration.

\section{Conclusion}

We can conclude from the results that this study monitored the effects of the crime news coverage in television on the audiences. Not much research has been done on this topic in the Pakistani perspective due to which it was a little difficult to gather the facts and particulars about the topic. But the research was very interesting and many interesting details came under the light. The results deduced after formulating the hypothesis and testing it were that after watching crime news coverage on Pakistani news media majority of the takes the society as an unsafe place and that the majority of the youth had the fear of becoming a crime victim themselves with an uncontrolled/open ended answers to simple questions.

While carrying out the research it was observed that after watching crime news people have developed an insecure and perilous feeling about the society and people around them. They avoid interacting with strangers and are careful to move around and have developed concern about their families. It was seen that females are much more affected by the impact of crime news than males.

\section{References}

1. Ortony A, Clore G, Collins A (1988) The cognitive structure of emotions Cambridge University Press, Cambridge.

2. Reber BH, Chang $\mathrm{Y}(2000)$ Assessing cultivation theory and public health model for crime reporting. Newspaper Research Journal 21: 99-112.

3. Anderson CA, Berkowitz L, Donnerstein E, Huesmann LR, Johnson JD, et al. (2003) The influence of media violence on youth. Psychological Science in the Public Interest 4: 81-110.

4. World Health Organization (2002). World report on violence and health Geneva.

5. Gerbner G (1998) Cultivation analysis: An overview. Mass Communication and Society 1: 175-194. 